\title{
Assessment of Innovation and Its Impacts on the Organisation in a Public Sector Organisation
}

\author{
Ishmael Ramorula \\ School of Business and Management Studies \\ Botswana Open University, Botswana \\ E-mail: ishmaelramorula1981@yahoo.com
}

\begin{abstract}
JE Agolla
Department of Management, School of Business and Management Studies

Botswana Open University, Botswana

E-mail: nyagonya2009@gmail.com
\end{abstract}

Received: March 17, 2018 Accepted: October 18, 2018 Published: October 25, 2018

doi:10.5296/ijmis.v3i1.13860 URL: http://dx.doi.org/10.5296/ijmis.v3i1.13860

\begin{abstract}
The paper presents an attempt to provide an assessment of innovativeness of the Botswana public sector and how its impacts on the overall business performance. To accomplish the study aims, a survey of a selected public sector organisation was carried out to gather information on the innovativeness and the impacts thereof on the overall performance of the sector. The hypotheses were tested using multivariate statistics. The study reveals that product and customer satisfaction are good predictors of innovativeness of organisation and have impact on the overall business performance. The other remaining variables did not indicate significance on the innovativeness and impacts on the selected public organisation's overall business performance. The present study's limitation is the focus on one public sector organisation. However, the study provides an insight into the innovativeness of Botswana's public sector and the impacts on the selected public sector's overall business performance. In addition, the study offers some recommendation on how the organisation can make use of the remaining variables to enhance its innovativeness. The study offers prima facie case of public sector innovativeness from a developing country, where little is known about innovation capabilities of the sector. Furthermore, the paper provides a more generalised, products and
\end{abstract}




\section{\begin{tabular}{rr} 
Macrothink & International Journal of Management $\begin{array}{r}\text { Innovation Systems } \\
\text { ISSN 1943-1384 } \\
\text { Instrtute }\end{array}$ \\
TM & 2018, Vol. 3, No. 1 \\
\hline
\end{tabular}}

customer satisfaction as predictors of organisation innovativeness.

Keywords: Creativity, New public management, Public sector, Organisation, Innovation, Africa, Botswana, Customer satisfaction, Market penetration 


\section{Mll Macrothink}

International Journal of Management Innovation Systems

ISSN 1943-1384

2018, Vol. 3, No. 1

\section{Introduction}

Innovation is considered to be a management discipline that is focused on the organisation's mission that searches unique opportunities, determines organisation's fitness to strategic directions and defines the measures for success Yeh-Yun and Yi-Ching (2007) in Nagy (2013) and Reguia (2014). Studies (Nagy, 2013; Popa, Preda, \& Boldea, 2010) view innovation as a process of creating a new customer oriented value as well as the main judge of organisations' competitiveness. Innovation can be defined as a process that add value to the organisation directly or indirectly for its customers and a degree of novelty to the organisation, suppliers and customers, developing new procedures, solutions, products and services and new ways of marketing (Lala, Gheorghe, \& Monica, 2010). There are many different types of innovations ranging from: product innovation, service innovation, process innovation, marketing innovation, technological innovation, position innovation, policy innovation, adoptive innovation, organisational innovation and paradigm innovation, which all allow organisations to realise competitive advantage and economic benefits (Reguia, 2014; Wright, Palmer, \& Perkins, 2005). On the one hand, for example, process innovation refers to adoption of new or significantly improved production methods or processes (Reguia, 2014). On the other hand, marketing innovation deals with satisfying customer needs and developing a competitive advantage through differentiation along one or more on product desired features such as the design, size, usability, quality, time, price, cost, savings, incremental revenue, product packaging, and product promotion (Popa et al., 2010; Reguia, 2014). Organisational innovation refers to the implementation of a new method in the organisation's business practices and workplace, whereas paradigm innovation is that type of innovation that depicts the organisation's new means of doing business (Marin-Garcia, Aznar-Mas, \& de Guevera, 2011).

\section{Botswana Context}

Public sector organisations (PSO) in Botswana have been faced with various challenges such as; poor financial performance, inept leadership, and the inability to align organisations' strategies with the ever-changing needs and expectations of customers. These have been demonstrated by the government's decision to privatise most of the public sector organisations. Such organisations that have bee earmarked for privatisation are: Botswana Telecommunications (BTC), National Development Bank (NDB) and Air Botswana (AB), just to mention a few. Currently there are ongoing talks to privatise Botswana Power Corporation (BPC), another giant parastatal and the sole provider of electricity generation and distribution in the entire country. The main reason often advanced is that these parastatals have failed to generate enough revenue in order to remain self-reliant. In most cases, these public organisations have failed to come up with more creative ways to remain competitive in the market and to meet the dynamic expectations of customers.

Despite the fact that a lot has been written on public sector's innovation, still there is dearth of literature on innovation in Botswana, focusing on public sector organisations (Botlhale, 2012; Tshukudu, 2014). The need to innovate is one of the determining factors that prompted the country to, among others, form parastatal organisations with the intention to capacitate 
the public sector to better serve the citizens almost a similar fashion to the private sector. This meant that these organisations became semi-autonomous, hence allowed to come up with new and more creative ways of service delivery, compete with the private sector for skilled human resource and devise strategic means through, which they can continue to be adaptable and relevant in the market (Botlhale, 2012; Tshukudu, 2014).

The Botswana Cattle Census between 2004 and 2015 estimated cattle population in the country to be around 2 million herds of cattle (Statistics Botswana, 2016). Against this number, BMC is expected to slaughter 10\%, which is about 200000 herds of cattle annually. However, the organisation has for the past 3 years fell short of this number slaughtering 99,132 cattle in $2014,103,995$ cattle in 2015 , and 91,818 cattle in 2016. These figures were far below the organisation's plant capacity. Apart from the markets the organisation has been exploiting, plans are also underway to penetrate the Russian and the Chinese markets given their markets size and structure. This is predicted to offer more economic benefits to BMC than the current markets. For the past three or so years, BMC has failed to make profits as compared to previous years. This is evidenced by the organisation's annual financial report of 2014 that reported a deficit of P21 million with its liabilities exceeding its assets by P252 million from P307 million in the year 2013 (BMC, 2014). In the year 2015 the organisation accumulated losses to the tune of P649 million compared to P896 million in 2014 (BMC, 2015). The organisation expenditure is more than its sales volumes according to the available records (BMC, 2015). This failure could be attributed to lack of creativity and innovativeness amongst other factors. BMC should device means of utilising the efficient and effective ways to penetrate more lucrative markets within other European markets. Moreover this may results in lowering the costs of materials' acquisition. BMC is continuing to be plagued by inefficiencies and with little innovative impact. This is evident from the organisation's performance that is far below the expected capacity. Therefore, the present study tries to address these two research questions:

$R Q 1$.What roles do innovation play in enhancing overall organisation's performance?

$R Q 2$. What are the possible innovative solutions that organisation's could explore to become competitive in both regional and global markets?

\section{Theoretical Framework and Hypotheses Development}

\subsection{Revenue Growth}

Organisations that innovate are able to always stay ahead of their competitors with regards to new inventions and in the process, attracting more customers and realising more economic benefits from their efforts (Agolla \& Van Lill, 2017). In another study (Eggert, Thiesbrummel, $\&$ Deutscher, 2014) state that organisations decide to innovate so as to be able to strengthen their competitive position, stabilise cash flows, protect the core product business, and generate additional revenue from existing and new customers. For example, (Eggert, Thiesbrummel, \& Deutscher, 2014) study covering 558 German industrial organisations over a three year period on service and product innovations, found a positive impact of product innovations on both revenue and profit growth. In a similar study (Kastalli \& Bart, 2013) on 


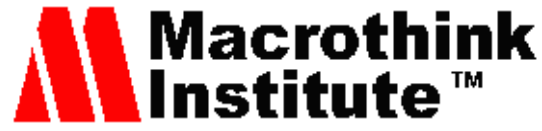

International Journal of Management Innovation Systems

ISSN 1943-1384

2018, Vol. 3, No. 1

the value creation and value proposition processes of 44 national subsidiaries of global manufacturing organisation turned product-service provider in 2001-2007 period found that the organisations were able to successfully transcend the inherent substitution of products by services, and to enact complementary sales dynamics between the two activities. Gunday et al. (2011) assert that there is a strong link between an organisation that innovate and increased sales, products, service consumptions, and utilisation thereby yielding additional profits to the organisation. Thus, it is hypothesised that:

H1. Innovative organisation will have increase in revenue growth that is positively statistically significantly related to organisation's performance.

\subsection{Cost Effectiveness}

Cost effectiveness demands for services that reach citizens even better along with pressures, to reduce costs from the core justifications for why innovation is important (Steen, 2009). For instance, to be termed as innovative, it must be replicable at a low cost and must cater for a specific needs (Ramalingam, Karim, Piaralal, \& Singh, 2015; Nanda, Kuruvilla, \& Murty, 2013). The rapid development in high technology, information and communication technologies has pushed many organisations to actively seek new ways, ideas, experimentation and creative solutions. These allows them to improve their current products, services, process, system and technology, as well as, ensuring that they are able to maximise on the revenue generation through reduction on the costs (Agolla \& Van Lill, 2016; Tan \& Narsudin, 2011). Coras (2014) opines that innovation plays a vital role in accelerating time for markets, for new products and services, improving product quality, accessing customers and suppliers' expertise outside of the organisation. In addition, this shortens the access to customers, resulting in an overall reduced costs spent on production and distribution of products and or services.

$\mathrm{Su}$ and Tang (2016) further add that the need to innovate and doing more with fewer resources has been evidenced during the recent economic crisis (2008-2009). This is because customers demanded goods at less costs as a result of the then financial instability. The result is, organisations had to come up with new strategies that ensure new products and services produced are cost effectively as determined by the financial environment. Furthermore, some organisations invested in research and development (R\&D) so as to allow the organisations to identify opportunities that can be exploited. This is to ensure that the product and service value chain is done in the most cost effective manner, which results with the end product that is also affordable to the target market (Coras 2014; Su \& Tang, 2016). Inspite of these, modernisation is linked to the technological innovation and new technology of products, new processes and services (Silva, Kovaleski, Gaia, Garcia, \& de Andrade Jr., 2012). This is attained through coming up with innovative ways that allows the establishment of priority projects. In addition that allow for reduction of waste, losses, an analysis of cost/benefit, coming up with enabling processes to quantify losses in physical measurement, and a continual progress monitoring (Silva et al., 2012; Gunday et al., 2011). Therefore, we hypothesised thus:

$H 2$. Innovative organisation is cost effectively positively statistically significantly related to 
performance.

\subsection{Market Penetration and Growth}

Organisations that have the willingness to exploit new markets and to achieve market growth portray both the ability to produce, process, organise and market innovatively (Prifti \& Alimehmeti, 2017). This is because of the organisations' ability to position themselves above their competitors. Innovation allows the organisations to enter and expand in new markets through new products, new methods of production, new distribution channels and better ideas of marketing the new or existing products and services (Agolla \& Van Lill, 2017; Maydeu-Olivares \& Lado, 2003). For example, another study in Kenya's soft drink market, Wainaina and Oloko (2012) point out those organisations, regardless of their sizes, strive to exploit new markets and to grow beyond their current status. This behaviour is found in different organisations ranging from net profit, revenue and other financial data, sales, number of employees, physical expansion, success of product line, and increased market share. This different growth measures affecting organisations are attributed to the innovation potential of organisations making them afloat and outsmarting their competitors (Prifti \& Alimehmeti, 2017; Beyene et al., 2016). Alhaddi (2016) for example carried out a study on some of the world's most profitable and innovative organisations and found that $50 \%$ of the US $\$ 864$ billion profit generated for 2015 was made by the top 15 organisations with their predominant sources of profitable growth varying from being innovative in product development to diversifying their products. It is therefore hypothesised that:

H3. Innovative organisation's market penetration and growth is positively statistically significantly related to organisation performance.

\subsection{Strategic Human Resource Management}

People and their collective skills, abilities and experience coupled with their ability to deploy these in the interests of the employing organisations are now recognised as making a significant contribution to organisations' success and constituting a major source of competitive advantage (Agolla, 2018; Waiganjo, Mukulu, \& Kahiri, 2012). The practices of strategic human resource namely: resourcing, training and development, employee relations, and reward management are concerned with how people are employed, and managed in organisations so as to achieve competitive advantage through the strategic deployment of a highly committed and capable workforce (Agolla, 2018; Golja \& Slivar, 2015; Waiganjo, Mukulu, \& Kahiri, 2012).

Innovation in an organisation is motivated by the organisation's anticipation of customer needs and wants (Steen, 2009). Golja and Slivar (2015) for instance state that innovative organisations are identifiable by the existence of strategic human resource practices. Moreover, Maier, Brad, Nicoara and Maier (2014) also assert that when an organisation develop new products or services and improve management processes, it requires the motivation and ability of human capital to produce creative ideas, develop innovative approaches and exert new opportunities. Hence, organisations that are innovative are recognised by their creative abilities and innovative characteristics during the recruitment and 


\section{Mll Macrothink}

International Journal of Management Innovation Systems ISSN 1943-1384 2018, Vol. 3, No. 1

selection process. Such organisations are likely to employ recruitment and selection process that results in employees' with diverse ideas and commitment to innovate behaviours (Maier et al., 2015; Bal, Bozkurt, \& Ertemsir, 2013). Bal, Bozkurt, and Ertemsir (2013) further opine that through effective staffing, employees become important sources of new ideas in the organisation's innovative process. In addition, a high level of employees' participation creates conditions that encourage them to inject new ideas and exchange knowledge in the ongoing innovation process and in turn enhancing innovative outcomes (Maier et al., 2015). For example, Waiganjo, Mukulu, and Kahiri (2012) point out that strategic human resource is an efficient function that allows the organisations to cope up with the environmental changes by changing passivity into initiatives, transmitting organisational goals, generating structural cohesion. Hence, act as an employee generated synergy that propels the organisation forward and create the best fit for the organisation's continued alignment to the changes in the business environment. Thus, it is hypothesis as follow:

H4. Innovative organisation will have strategic human resource management practices that are positively statistically significantly related to organisation performance.

\subsection{Product Development}

The intensity of competition and the rate of change in customers taste are continuously forcing organisations to generate new products and service packages at a very fast rate and lower costs (Beyene, Shi, \& Wu, 2016). This is perceived as a core organisational process that creates superior customer values and supports the overall organisational performance. Other than product innovation being considered as just coming up with a new product, it is again a measure of the commercial outcome, the level of customer satisfaction and the overall project performance of the innovation process (Beyene, Shi, \& Wu, 2016). Amue and Adiele (2012) point out that one of the signs of an organisation that appreciates and an implements innovation strategy is through emergence of new products within the organisation. This is known as new to the world products and /or service packages, new category entry products or services (new product lines). This includes product line (product that are line extensions), coming up with new improvements to the existing products (current products made better) and service packages and repositioning a new application for an existing product (Udegbe \& Udegbe, 2013).

Product development in organisations is explained as the development of new products, product improvements, product modifications and coming up with new brands through the organisations' own R\&D (Agolla \& Van Lill, 2017; Amue \& Adiele, 2012). The strategy follows the stages of idea generation from the organisation's employees as a result of the environmental stimulus, idea screening, concept development and testing, marketing strategy development, business analysis, product development, test marketing and commercialisation (Agolla \& Van Lill, 2016; Amue \& Adiele, 2012; Chandra \& Neelankavil, 2008). Thus, it is hypothesised that:

H5. Innovative organisation's product development is positively statistically significantly related to organisation performance. 


\subsection{Customer Satisfaction}

Customers are often seen as the basis of organisation's profitability (Pishgar, Dezhkam, Ghanbarpoor, Shabani, \& Ashoori, 2013). With customer satisfaction having gained momentum over the last few decades, organisations have since channelled their innovation efforts towards coming up with ways that would allow them to control customer defection and gain access to new customers (Pishgar et al., 2013; Prifti \& Alimehmeti, 2017). Senguo and Kilango (2015), state that, customer satisfaction is one of the fundamental indicators of organisation's innovation performance because of its behavioural and economic consequence on an organisation. Customers' perceptions on service innovation, in terms of organisation innovation, process innovation, and product innovation help in increasing customer satisfaction Nanda et al. (2013). Senguo and Kilango (2015) add that innovation has a significant effect on customer loyalty because it influences factors such as customer expectation, perceived quality, perceived value, corporate image, customer satisfaction, customer confidence and customer commitment.

Innovation is seen as a strong driver of both customer satisfaction and organisation performance in service industries in general (Bellingkrodt \& Wallenburg, 2015). Yi and Gong (2009) also add that innovation in the form of offering new or enhanced services increases the value of the service delivered. Hence, proving that innovation is vital antecedent to higher customer satisfaction and loyalty. First, the customer is a potential source of information, the more and the better information available, the higher potential for innovativeness of the organisation, and the better services and products provision to the same customers (Bellingkrodt \& Wallenburg, 2015). Second, through the transformation, exploitation of this new knowledge acquired from interaction with customers, insights and ideas are generated. This strengthens the innovativeness of the organisations and ultimately, improved customer service provision and enhanced satisfaction (Forsman, 2011).

Bhaskar (2011) observes some critical factors such as enhanced personal communication; consistent products and physical features influence service quality that has an effect on customer satisfaction. Nanda, Kuruvilla and Murty (2013) also state that innovation in every sector can bring customer satisfaction and trustworthiness as it offers new features, which fulfill their desires. Hence, organisations have to make strategies for continuous innovation to satisfy customer base, be it innovation in services offered or product related features. An empirical study carried out to explore customer satisfaction in relation to service innovation and customer value in locally renowned chain hotels in Taiwan, found that customers' perceptions of service innovation in terms of organisation innovation, process innovation and production innovation helped in increasing customer satisfaction (Ming-horng, Jih-Lian, Yi-Chou, \& Chung-Lin, 2012). Thus, it is posited that:

H6. Customer satisfaction is positively statistically significantly related to organisation innovative performance.

\subsection{Organisational Performance}

The organisation's ability to continuously develop innovation activities is source of long term 
organisation's success (Atalay, Anafarta, \& Sarvan, 2013). An organisation that innovates may experience improved performances in either financial or non-financial indicators. Consequently, organisations that innovate are also able to realise an increased market share, return on capital employed, return on investment, number of new customers, ability to gain repeat business, increased profits and increased sales (Sethibe \& Steyn, 2015; Tajuddin, Iberahim, \& Ismail, 2015). Study, for example, Tajuddin, Iberahim and Ismail (2015) of 721 manufacturing organisations in the United Kingdom, found that the numbers of innovation achieved by organisations had positive effects on those organisations' operating profit margins. Furthermore, they found that innovative organisations in general were more profitable than non-innovative organisations. Moreover, organisations' administrative and technical innovativeness had positive impact on their performances. Similarly, Gunday et al.'s (2011) study also explored the effect of product, process, organisation and marketing innovations on different aspects of organisation performance including production, marketing and finance empirically in Turkish manufacturing organisations found that products, organisation and marketing have positive effects on organisations performances. Atalay et al. (2013), for example argue that organisations that innovate are able to reduce their administrative costs, transactional costs and costs of supplies. For instance, introduction of management systems for general production like supply chain management, business re-engineering, lean production and quality management systems. We therefore posit that:

$H 7$. Organisation innovativeness will have a significance statistically positive relationship with the overall business performance.

\section{Research Methodology}

\subsection{Research Design}

The study was carried out from March 2017 to September 2017. The study's location was Botswana. The study's sample organisation was the Botswana Meat Commision (BMC). The organisation comprises 1127 employees, of which 239 employees are based in Maun, 153 employees in Francistown and Lobatse being the headquarters with 735 employees. In addition to its proximity and population, Lobatse offers a good location to conduct this type of study, as it is hosts to senior management team that controls the entire BMC operations. Permission was obtained from the organisation requesting them to participate in the present study survey. After obtaining the permission, appointment was made between a contact person and the researchers on the modalities of administering questionnaire to the participants. The choice of the research location was guided by the resource constraints particularly time, hence the study only focused on Lobatse plant because of its proximity and population as compared to the rest of the subsidiary organisations.

\subsection{Instrument Development}

The research questionnaire was developed after a careful and thorough review of relevant literature on innovation. The instrument piloted in the organisation on 20 employees with the knowledge of innovation and their inputs were incorporated into the final instrument. This assisted in refinement of final instrument in terms or reliability. The study's instrument was 


\section{Mll Macrothink}

International Journal of Management Innovation Systems

ISSN 1943-1384

2018, Vol. 3, No. 1

divided into nine sections (sections A to $\mathrm{H}$ ). The instrument was based on Likert type scale ranging from 1 strongly disagree (SD) to 5 strongly agree (SA). The main variables of the instrument were as follows: economic benefit, five items (Eggert et al., 2014); Kastalli \& Bart, 2013), Gunday et al., 2011; Nanda et al., 2013; Tan \& Narsudin, 2011; Coras, 2014). Market penetration and growth, five items (Maydeu-Olivares \& Lado 2003; Wainaina \& Oloko 2012; Prifti \& Alimehmeti 2017; Beyene et al., 2016; Alhaddi, 2016). Strategic human resource management, five items (Maydeu-Olivares \& Lado, 2003; Wainaina \& Oloko, 2012; Prifti \& Alimehmeti, 2017; Beyene et al., 2016; Alhaddi, 2016). Product development, five items (Beyene et al., 2016; Amue \& Adiele, 2012; Udegbe \& Udegbe, 2013; Amue \& Adiele, 2012). Customer satisfaction, five items (Pishgar et al., 2013; Prifti \& Alimehmeti, 2017; Kilango, 2015; Nanda et al., 2013; Senguo \& Kilango, 2015; Bellingkrodt \& Wallenburg, 2015) and organisation's performance, five items (Tajuddin et al., 2015; Atalay et al., 2013; Gunday et al., 2011; Mafini, 2015).

\subsection{Sampling Procedure}

A sample was selected from the population of 277 employees using random purposive sampling method. The questionnaires were self-administered directly to the participants, and collection at a later date was agreed on. Fully completed and returned questionnaires were 105, giving a return rate of 15 percent. In order to ensure that participants are equally represented in the survey, we adopted stratified random sampling covering all the sections of the organisation to administer the questionnaires to the participants.

\section{Results}

The study performed descriptive statistics, factor analysis, Pearson's product-moment, and multiple regressions to present the empirical results.

\subsection{Descriptive Analysis}

The descriptive statistics computed for the study are presented first in an outline of the characteristics of the sample with regards to the variables included in the study.

Table 1 indicates that the majority of the respondents are males comprising $76 \%$ of the sample, while female respondents constituted $24 \%$, means that the organisation is male dominated. The significant difference in the number also of male and females could be attributed to the nature of the business that is, abattoir, labour intensive, and in most cases females tend to shy away from such jobs as opposed to their male counterparts. With respect to the age distribution of the respondents, it may be seen that only 3 were in the age group $20-25$, with a further $11 \%$ being in the age group 25-30 while $26 \%$ of the sample were in the age group 30-35. The age category $30-35$ is the majority followed by $35-40$, which has $25 \%$ of the respondents. These categories are active in the employment mainstream, hence being in the majority of respondents who took part in the study. In addition, it means most of the BMC employees are still in their youthful age and active. 


\section{Macrothink \\ International Journal of Management Innovation Systems \\ ISSN 1943-1384 2018, Vol. 3, No. 1}

Table 1. Demographic

\begin{tabular}{|c|c|c|c|}
\hline Description & Characteristics & Frequency & Percentage (\%) \\
\hline \multirow[t]{2}{*}{ Gender } & Male & 80 & 76.2 \\
\hline & Female & 25 & 23.8 \\
\hline \multirow[t]{7}{*}{ Age } & $20-25$ & 3 & 2.9 \\
\hline & $25-30$ & 12 & 11.4 \\
\hline & $30-35$ & 27 & 25.7 \\
\hline & $35-40$ & 26 & 24.8 \\
\hline & $40-45$ & 18 & 17.1 \\
\hline & $45-50$ & 12 & 11.4 \\
\hline & 50 and above & 7 & 6.7 \\
\hline \multirow[t]{6}{*}{ Education level } & Certificate & 26 & 24.8 \\
\hline & Diploma & 33 & 31.4 \\
\hline & Degree & 40 & 38.1 \\
\hline & Masters & 5 & 4.8 \\
\hline & $\mathrm{PhD}$ & 1 & 1.0 \\
\hline & Certificate & 26 & 24.8 \\
\hline \multirow[t]{5}{*}{ Work Experience } & $0-5 y e a r s$ & 17 & 16.2 \\
\hline & 5-10years & 39 & 37.1 \\
\hline & 10-15years & 22 & 21.0 \\
\hline & 15-20years & 10 & 9.5 \\
\hline & 20years and above & 17 & 16.2 \\
\hline
\end{tabular}

Table 1 reveals that $38 \%$ of the sample had degree qualifications. Those who had completed Diploma constituted $31 \%$ of the sample. These were followed by $25 \%$ of those employees who have certificate level qualifications, and those with Masters Qualifications comprised $5 \%$ of the respondents. Only one respondent has a $\mathrm{PhD}$ qualification. Below is a presentation of the descriptive statistics in the form of mean, standard deviation for the above distribution.

With respect to number of years of experience or service, $37 \%$ of the sample had been in the organisation for $5-10$ years. A further $21 \%$ of the respondents had been in the organisation for 10-15 years, and $16 \%$ had been in the organisation for $0-5$ years and 20 years and above respectively. The results are a strong indication that the organisation is capable of retaining its employees for longer periods serving the organisation. The information given by the respondents in relation to the study is therefore based on their long term experience in the organisation. 


\subsection{Reliability and Validity Test}

To test for reliability and validity, we performed factor analysis using Crobanch's alpha coefficient. The results for all the variables and their average corresponding Crobanch's $\alpha$ coefficient are shown in Table 2 below.

Table 2. Cronbach's alpha coefficient

\begin{tabular}{lc}
\hline Items (Latent variables) & Cronbach's $\boldsymbol{\alpha}$ coefficient \\
\hline Economic benefits (Revenue growth) - (5 items) & 0.887 \\
Economic benefit (Cost effectiveness) - (5 items) & 0.875 \\
Market penetration (5 items) & 0.651 \\
Strategic human resource management (5 items) & 0.795 \\
Product development (5 items) & 0.745 \\
Customer satisfaction (5 items) & 0.847 \\
Overall performance (5 items) & 0.903 \\
\hline
\end{tabular}

From Table 2 we can deduce that overall reliability based on Cronbach's alpha is above the cut-off limit of 0.6 , signifying a reasonable internal reliability and consistency of the items (Nunally, 1978).

\subsubsection{Correlation Analysis}

To determine the strength and direction of the linear relationship between two continuous variables, we performed Pearson's product-moment correlation coefficient as shown in Table 3. It is evaluated by using Pearson product-moment correlation coefficient. The degree of relationship is indicated by the absolute value of the coefficient. A correlation coefficient close to zero means lack of any form of relationship. It is important to note that correlation analysis is basically used to examine the existence of statistically significant relationship between two variables. In this case, correlation was performed to assist with discriminant validity between constructs or factors. It is expected that items should correlate more strongly with their own construct than with any other, hence demonstrating that they are perceived by participants as belonging to their theoretical constructs (Messick, 1988).

Correlation analysis was used to describe the strength and direction of the linear relationships between the innovation factors, which are: economic benefits, market penetration and growth, strategic human resource, product development, customer satisfaction and BMC's overall performance. The results of multiple correlation analysis revealed that most of the variables, constituted by summing the scores on individual items, which constituted each scale, were positive and moderate. However, correlation coefficients between a few variables were fairly high. This include relationship between economic benefits and market penetration $\left(0.716^{*}\right)$, economic benefits (Revenue growth) and economic benefits (cost effectiveness), which exhibited a correlation coefficient of $0.764^{*}$, and lastly, the relationship between strategic human resource and economic benefits (cost effectiveness) had a correlation coefficient of 
$0.703 *$

In the cases where the Pearson-product moment correlation coefficients were high, the interpretation is that high level of such variables are associated with high levels of the other variable. In general, such variables are described as displaying high positive relationships. The tests were carried out at the 0.05 level of significance ( 1 tailed). The study uses the single upper (1- tailed) asymmetric test since the assumption was that the direction of relationship between the predictor variables and BMC'S overall satisfaction is always positive. All correlation coefficients were statistically significant $(p<.005)$. The table below shows the relationships between all the seven variables.

Table 3. Product-moment correlations between variables

\begin{tabular}{lllllll}
\hline Measures & (1) & (2) & (3) & (4) & (5) & (6) \\
\hline Economic Benefit (Revenue growth) & & & & & & \\
Economic Benefit (Cost effectiveness) & $0.76^{*}$ & & & & & \\
Market penetration and growth & $0.61^{*}$ & $0.72^{*}$ & & & & \\
Strategic Human Resources Management & $0.66^{*}$ & $0.61^{*}$ & $0.60^{*}$ & & & \\
Product development & $0.61^{*}$ & $0.60^{*}$ & $0.56^{*}$ & $0.60^{*}$ & & \\
Customer satisfaction & $0.67^{*}$ & $0.64^{*}$ & $0.54^{*}$ & $0.61^{*}$ & $0.65^{*}$ & \\
BMC's overall performance & $0.52^{*}$ & $0.58^{*}$ & $0.44^{*}$ & $0.56^{*}$ & $0.61^{*}$ & $0.59^{*}$ \\
\hline $\mathbf{N = 1 0 5} * \boldsymbol{p}<\mathbf{. 0 0 5}$ & & & & & & \\
\hline
\end{tabular}

\subsubsection{Regression Results}

Multiple regression analysis was performed to explore the effect of the independent variables on BMC's overall performance, which is the response variable. The independent variables are; economic benefits (cost effectiveness), market penetration and growth, strategic human resource management, product development and customer satisfaction.

Preliminary analysis was carried out to ensure that there was no serious violation of model assumptions on multi-collinearity, linearity and homoscedasticity. The results revealed that correlations between the dependent and independent variables were all greater than 0.3 (Tabachnick \& Fidell, 2002). Choice was made to drop variables, which were highly correlated from the analysis. These include; economic benefits (Revenue growth) and market penetration. However, in the resulting model, all variables were retained including economic benefits (cost effectiveness) despite its relatively high correlation with strategic human resource variable $(0.703)$ due to its uniqueness and significance in the model. The residual scatter plots were roughly rectangular in shape while the normal probability plots also showed that the assumptions were not violated. The final regression model comprised the following predictors; Economic benefits (cost effectiveness), product development, strategic human resource and customer satisfaction. The dependent variable was BMC's overall performance. 


\section{MIN Macrothink}

\subsubsection{Full Model Evaluation}

The overall model explains approximately $46 \%$ of the variance in the dependent variable $\left(R^{2}\right.$ $=0.458$ ). This is quite a modest result. It can be deduced that the set of independent variables altogether gave a good prediction of the overall performance of BMC (see table 3 below).

Table 4. Summary of regression model

\begin{tabular}{cccccccccc}
\hline Model & $\mathbf{R}$ & $\mathbf{R}^{\mathbf{2}}$ & Adjusted R $^{\mathbf{2}}$ & $\begin{array}{c}\text { Standard } \\
\text { error }\end{array}$ & $\begin{array}{c}\text { Sum of } \\
\text { squares }\end{array}$ & df & $\begin{array}{c}\text { Mean } \\
\text { square }\end{array}$ & $\mathbf{F}$ & Sig. \\
\hline 1 & $0.692^{\mathrm{a}}$ & 0.479 & 0.458 & 3.301 & 1003.049 & 4 & 250.762 & 23.012 & $.000^{\mathrm{b}}$ \\
& & & & & 1089.713 & 100 & 10.897 & & \\
& & & & & 2092.762 & 104 & & & \\
\hline
\end{tabular}

Note. a. Predictors: (Constant), customer satisfaction, strategic human resource, product development, economic benefit; b. Dependent variable: BMC overall performance.

The above results in Table 4 are also statistically significant, as demonstrated in the ANOVA, which tests the null hypothesis, that multiple $R$ in the population equals 0 ( $\mathrm{sig}=0.000$, implying that $p<0.005$ ).

\subsubsection{Evaluation of Individual Predictor Variables}

In order to understand the unique impact of the predictors in the model, the standardised coefficients, (Beta values) are analysed further. A beta value, which has the largest absolute size, is an indication that the particular independent variable associated with it contributed the most in explaining the overall variance in the response variable when other variables are controlled for. The results of the regression model indicate that, product development is the most important contributor, with value of $(\beta=0.296)$, followed by followed by customer satisfaction $(\beta=0.213)$. The least important predictor is strategic human resource. The important question to ask is; are the contributions of the variables statistically significant? This is addressed by observing the column marked sig. It shows that only customer satisfaction and product development significantly contributed to the total variance in BMC's overall performance $(\mathrm{sig}<.05)$ as shown Table 5. 
Table 5. BMC's overall performance

\begin{tabular}{|c|c|c|c|c|c|}
\hline \multicolumn{6}{|c|}{ Coefficient } \\
\hline \multirow[t]{2}{*}{ Model } & \multicolumn{2}{|c|}{$\begin{array}{c}\text { Unstandardised } \\
\text { Coefficients }\end{array}$} & \multirow{2}{*}{$\begin{array}{c}\begin{array}{c}\text { Unstandardised } \\
\text { Coefficients }\end{array} \\
\text { Beta }\end{array}$} & \multirow[t]{2}{*}{$\mathbf{t}$} & \multirow[t]{2}{*}{ Sig. } \\
\hline & B & Std. Error & & & \\
\hline 1 (Constant) & 1.041 & 1.144 & & 0.909 & 0.365 \\
\hline Economic benefits & 0.153 & 0.099 & 0.171 & 1.537 & 0.128 \\
\hline Strategic human resource & 0.122 & 0.102 & 0.130 & 1.195 & 0.235 \\
\hline Product development & 0.337 & 0.116 & 0.296 & 2.909 & 0.004 \\
\hline Customer satisfaction & 0.209 & 0.104 & 0.213 & 2.013 & 0.047 \\
\hline
\end{tabular}

Note. a. Dependent Variable: BMC'S overall performance.

In general, the result of regression analysis indicates that the full model, comprising four predictor variables, explained $0.479(48 \%)$ of the total variance in BMC's overall performance. However, only two variables being product development and customer satisfaction, reached statistical significance.

\section{Discussion}

The deduction from the statistical analysis (Table 4) indicates that this independent variable gives a good prediction of the overall innovative performance of BMC. These results are also consistent with the study (Prifti \& Alimehmeti, 2017), which explained that organisations that have the willingness to exploit new markets, achieve market growth, portrays both the ability to produce, process, organise and market innovatively.

\subsection{Market Penetrations and Growth}

The results in Table 4 indicate that market penetration and growth is a good predictor of the overall innovative performance of the organisation, though the results in Table 5 indicates that only product development and customer satisfaction reached statistical significance. Previous studies (Prifti \& Alimehmeti, 2017; Beyene et al., 2016) point that the different growth measures affecting different organisations are attributed to the innovation potential of organisations making them afloat and out-smarting their competitors. This is further supported by Alhaddi (2016) study's, which found that the top organisations are able to realise profitable growth because of their ability to innovate in product development and to diversifying their products and services.

\subsection{Strategic Human Resource Management}

The result obtained from (Table 3) indicates that strategic human resource management is a good predictor of the overall innovative performance of organisation. However, the result of (Table 5) indicates that this strategic human resource management did not reach statistical significance. These results find solace in other studies (Waiganjo et al., 2012; Steen, 2009; Golja \& Slivar, 2015) which indicate that organisations that innovate are identifiable by the existence of strategic human resource practices such as; employees' collective skills, abilities 
and experience coupled with their ability to deploy these in the interests of the organisation are now recognised as making a significant contribution to organisation's success and as such constituting a major source of competitive advantage.

\subsection{Product Development}

The results (Table 4) indicate that product development is a good predictor of the overall innovative performance of organisation. In addition the result of (Table 4) also indicates that the variable reached statistical significance. This is consistent with study (Beyene et al., 2016), which found that the intensity of competition and the rate of change in customers taste are continuously forcing organisations to generate new products and service packages at a very fast rate and lower costs, which is perceived as a core organisational process that creates superior customer values and supports the overall organisational performance. The study also corroborated (Amue \& Adiele, 2012; Udegbe \& Udegbe, 2013) findings that one of the signs of an organisation that appreciates and implements innovation strategies is through emergence of new products within the organisation, known as new-to-the-world products and or service packages, new category entry products or services (new product lines). In addition to product line (product that are line extensions), coming up with new improvements to the existing products (current products made better) and service packages and repositioning a new application for an existing product.

\subsection{Customer Satisfaction}

The result of statistical analysis (Table 4) indicates that customer satisfaction is a good predictor of the overall innovative performance of BMC with the result of (Table 5) also indicating that the variables reached statistical significance. This is consistent with previous studies (Pishgar et al., 2013; Prifti \& Alimehmeti, 2017). This result also found support from Senguo and Kilango (2015) study's, which established that customer satisfaction is one of the fundamental indicators of organisation's innovation performance. Moreover studies (Nanda et al., 2013; Senguo \& Kilango, 2015) also opine that customers' perceptions on service innovation, in terms of organisation innovation, process innovation, and product innovation help in increasing customer satisfaction, customer confidence and customer commitment.

\section{Conclusion}

The results of regression analysis indicate that though the independent variables are good predictors of the organisation performance, but only two variables (product development and customer satisfaction) were found to have reached statistical significance. The present study's results seem to deviate from the mainstream literature on innovation and organisation performance, which found that there are strong relationships between the investigated variables and organisation performance. Many factors could have contributed to this for example, the sample's freedom to express themselves when responding to questions or the timing of distribution of research instruments. The conclusion that could be drawn is that the respondents identified product development and customer satisfaction as the predictors of organisation innovative performance.

Another conclusion that can be drawn from the study is that employees view the organisation 
as lacking innovative approaches. The study revealed that for the organisation to realise economic growth, market penetration and growth, then they should develop their products, services and to satisfy customers. Thereafter, the organisation needs to acknowledge and reward employees for their creativeness and innovativeness. This is because when employees are allowed an opportunity to exploit their creativeness, they always look to explore their environment more, hence come up with new and better ways of doing things. Again the present study noted that the organisation should invest in $R \& D$. This would allow the organisation to acknowledge the dynamics in the market, the needs and expectation of customers and be able to align the products and services to what the market wants.

The study also established that the organisation should consider hiring creative people and training employees on innovation. Effective staffing and training make employees become important sources of new ideas in the organisation's innovative process. Their high level of participation encourages them to bring new ideas and exchange knowledge in the on-going innovation process consequently, enhancing innovative outcomes (Bal et al., 2013; Maier et al., 2015). The organisation should also engage customers and stakeholders by soliciting their feedback and carrying out customer surveys. Customer engagement allows the organisation to get a feel of what would serve customers better, hence giving the organisation an opportunity to align its corporate strategy to satisfying customers' needs. Moreover, because customers would be better served, this would allow the organisation to retain its customers and attract new business (Sethibe \& Steyn, 2015; Tajuddin et al., 2015).

\subsection{Contributions of the Study}

The present study contributes to public sector innovation literature through empirical evidence gathered data using quantitative approach. BMC like other public sector organisations was established through an Act of Parliament. This compels BMC organisations to have policies in place that are aligned to realising the mandates of this very Act. The present study therefore exists to assist the organisation to formulate the governance tools that can incorporate policies on innovation that would incorporate innovation in both the corporate and the operational strategies. In addition, managers can use the results of this study in designing products, and services to penetrate markets, as there is evidence that product innovation and customer satisfaction are good predictors of organisation performance.

Despite the aforementioned contributions of the study, we bring to the attention of the readers some limitations, which need to be taken into account. The present study focused on BMC as one of the public sector organisations in Botswana, therefore other public sector in Botswana may need to be considered separately when interpreting these results. Methodologically we relied on a cross-sectional study therefore we urge other scholars to consider longitudinal study. In addition, we also encourage future researchers to consider mixed research methods to compensate for the weaknesses that are inherent with the single method approach. The results of the present study presented some gaps that exist in the innovative capabilities of the public sector organisations and the recommendations that can help improve the competiveness of the public sector performance. 


\section{$\triangle$ Macrothink}

International Journal of Management Innovation Systems

ISSN 1943-1384

2018, Vol. 3, No. 1

\section{References}

Agolla, J. E. (2018). Human Capital in Smart Manufacturing and Industry 4.0 Revolution. In Digital Transformation in Smart Manufacturing. Retrieved from http://www.intechopen.com/articles/show/title/human-capital-in-the-smart-manufacturing-an d-industry-4-0-revolution

Agolla, J. E., \& Van Lill, J. B. (2013). Public Sector Innovation Drivers: A process Model. Journal of Social Sciences, 34(2), 165-176. https://doi.org/10.1080/09718923.2013.11893128

Agolla, J. E., \& Van Lill, J. B. (2016). An empirical investigation into innovation drivers and barriers in public sector organisations. International Journal of Innovation Science, 8(4), 404-422. https://doi.org/10.1108/IJIS-06-2016-0006

Agolla, J. E., \& Van Lill, J. B. (2017). A structural equation modelling of innovation in public sector organisations. African Journal of Business and Economic Research, 12(1), 107-140. https://doi.org/10.31920/1750-4562/2017/v12n1a5

Alhaddi, A. H. (2016). An exploratory paper on strategy implementation: Industry look at some of the world's most profitable and most innovative organisations. Journal of Management and Strategy, 7(4). https://doi.org/10.5430/jms.v7n4p1

Amabile, M. T. (2012). Componential Theory of Creativity. Boulder, CO: Westview Press. Harvard Business School. Boston, Massachusetts.

Amue, G. J., \& Adiele, C. K. (2012). New product development and consumer innovative behaviour: An empirical validation study. European Journal of Business and Social Sciences, 1(6), 7-109.

Anderson, N., Potocnik, K., \& Zhou, J. (2012). Innovation and creativity in organisations: A state of-the-science review, prospective commentary and guiding framework. Journal of Management, 40(5), 1247-1333.

Atalay, M., Anafarta, N., \& Sarvan, F. (2013). The relationship between innovation and organisation performance: An empirical evidence from Turkish automotive supplier industry. Procedia - Social and Behavioural Sciences, 75, 226-235. https://doi.org/10.1016/j.sbspro.2013.04.026

Bal, Y., Bozkurt, S., \& Ertemsir, E. (2013). A Study on Determining the Relationship between Strategic HRM Practices and Innovation in Organisations. Active Citizenship by Knowledge Management and Innovation, Management, Knowledge and Learning. International Conference, Zadar. Croatia.

Bekhet, K. A., \& Zauszniewski, A. J. (2012). Methodological Triangulation: An approach to understanding data.

Bellingkrodt, S., \& Wallenburg, M. C. (2015). The role of customer relations for innovativeness and customer satisfaction: A comparison of service industries. The International Journal of Logistics Management, 26(2), 254-274. 
https://doi.org/10.1108/IJLM-06-2012-0038

Beyene, T. K., Shi, S. C., \& Wu, W. W. (2016).The Impact of Innovation Strategy on Organisational Learning and Innovation Performance: Do organisation size and ownership type make a difference? South African Journal of Industrial Engineering, 27(1), 125-136. https://doi.org/10.7166/27-1-1308

Bhaskar, U. N., \& Raja, S. B. (2011). Impact of service quality on Apparel retail customer satisfaction: A study of select metropolitan city Hyderabad. Journal of Management Research, $3(2), 1-13$.

Botlhale, E. (2012). Privatisation in Botswana. A case of First Not Happening First? Research in Applied Economics, 4(1), 1-15. https://doi.org/10.5296/rae.v4i1.657

Botswana Meat Commission. (2013). History of the organisation. Retrieved from http://www.bmc.bw/content/id/3/History\%20and\%20Organisation

Brinkerhoff, W. D., \& Brinkerhoff, M. J. (2015). Public Sector Management Reform in Developing Countries: Perspective beyond NPM Orthodoxy. Public Administration and Development. John Wiley and Sons, Ltd. https://doi.org/10.1002/pad.1739

Camison, C., \& Villar-Lopez, A. (2011). Non-technical innovation: organisational memory and learning capacities as antecedent factors with effects on sustained competitive advantage. Industrial Marketing Management, $\quad 40, \quad 1294-1304$. https://doi.org/10.1016/j.indmarman.2011.10.001

Cankar, S. S., \& Petkovsek, V. (2013). Private and Public Sector Innovation and the Importance of Cross - Sector Collaboration. The Journal of Applied Business Research, 29(6), 1597-1606. https://doi.org/10.19030/jabr.v29i6.8197

Cekmecelioglu, G. H., \& Gunsel, A. (2013). The effect of individual creativity and organisational climate on organisation innovativeness. Procedia - Social and Behavioural Sciences, 99, 257-264. https://doi.org/10.1016/j.sbspro.2013.10.493

Chandra, M., \& Neelankavil, P. J. (2008). Product development and innovation for developing countries: Potential and challenges. Journal of Management Development, 27(10), 1017-1025. https://doi.org/10.1108/02621710810916277

Coras, L. E. (2014). Open Innovation - The Good, The Bad, The Uncertainties. The USV Annals of Economics and Public Administration, 14(1), 38-47.

Cruiz, S., \& Paulino, S. (2013). Public Service Innovation and Evaluation Indicators. Journal of Technology Management and Innovation, 8, 285-297. https://doi.org/10.4067/S0718-27242013000300026

Daglio, M., Gerson, D., \& Kitchen, H. (2014). Building Organisational Capacity for Public Sector Innovation. Background Paper prepared for the OECD Conference. Innovating the Public Sector: from Ideas to Impact. Paris 12-13 November 2014.

Denscombe, M. (2008). Communities of practice: A research paradigm for the Mixed 


\section{MInstitute Macrothink $^{\text {Int }}$}

International Journal of Management Innovation Systems ISSN 1943-1384 2018, Vol. 3, No. 1

Methods approach. Journal of Mixed Method Research, 2(3), 7-22. https://doi.org/10.1177/1558689808316807

Economic Commission for Africa. (2010). Innovations and Best Practices in Public Sector Reforms: The Case of Civil Service in Ghana, Kenya, Nigeria and South Africa. Retrieved from http://www.uneca.org

Eggert, A., Thiesbrummel, C., \& Deutscher, C. (2014). Differential effects of product and service innovations on the financial performance of industrial organisations. Jbm Research Article, 7(3), 380-405.

Emani, R., Moradi, E., Idrus, D., \& Almutairi, O. D. (2012). Investigating the Relationship between Organisational Learning Cultures, Job Satisfaction Turnover Intention in SMEs. International Journal of Innovative Ideas, 2(1), 8-23.

Feinberg, W. (2012). Critical Pragmatist and the Reconnection of Science and Values. European Journal of Pragmatism and American Philosophy, 14(1), 222-240. https://doi.org/10.4000/ejpap.786

Fereday, J., \& Muir-Cochrane, E. (2006). Demonstrating Rigor Using Thematic Analysis: A Hybrid Approach of Inductive and Deductive Coding and Theme Development. International Journal of Qualitative Methods, 5(1), 80-92. https://doi.org/10.1177/160940690600500107

Ford, C. M. (1996). A theory of individual creative action in multiple social domain. The Academy of Management Review, 21(4), 1112-1142. https://doi.org/10.5465/amr.1996.9704071865

Forsman, H. (2011). Innovation capacity and innovation development in small enterprises. A comparison between the manufacturing and service sectors. Research Policy, 40(5), 739-750. https://doi.org/10.1016/j.respol.2011.02.003

Fox, J. (2009). Regression Diagnostics. McMaster University, Canada.

Gill, P., Stewart, K., Treasure, E., \& Chadwick, B. (2008). Methods of data collection in qualitative research: Interviews and focus group. British Dental Journal, 204, 291-295. https://doi.org/10.1038/bdj.2008.192

Golafshani, N. (2003). Understanding Reliability and Validity in Qualitative Research. The Qualitative Report, 8(4), 597-606.

Gunday, G., Ulusoy, G., Kilic, K., \& Alpkan, L. (2011). Effect of Innovation Types of organisation Performance. International Journal of Production Economics, 133(2), 662-676. https://doi.org/10.1016/j.ijpe.2011.05.014

Hansen, E. B. (1999). Testing for Linearity. Journal for Economic Surveys, 13(5), 1-26. https://doi.org/10.1111/1467-6419.00098

Hassan, U. M., Shaukat, S., Nawaz, S. M., \& Naz, S. (2013). Effect of Innovation Types on organisation Performance: An Empirical Study on Pakistan's Manufacturing Sector. Pakistan Journal of Commerce and Social Sciences, 7(2), 243-262. 


\section{$\Lambda$ Macrothink}

International Journal of Management Innovation Systems ISSN 1943-1384 2018, Vol. 3, No. 1

Hope, K. R. (2001). The New Public Management: Context and Practice in Africa. International Journal of Management, 4, 119-134. https://doi.org/10.1016/S1096-7494(01)00053-8

Hutcheson, D. G. (2011). Data Coding, management and manipulation. Journal of Modelling in Management, 6(1), 123-132. https://doi.org/10.1108/jm2.2011.29706aab.001

Ihuah, W. P., \& Eaton, D. (2013). The Pragmatic Research Approach: A Framework for Sustainable Management of Public Housing Estates in Nigeria. Journal of US - China Public Administration, 10(10), 933-944.

Kastalli, I. V., \& Bart, V. L. (2013). Servitization: Disentangling the impact of service business model innovation on manufacturing organisation performance. Journal of Operations Management, 31(4), 169-180. https://doi.org/10.1016/j.jom.2013.02.001

Keppel, G., \& Zedeck, S. (1989). Data analysis for research designs: Analysis-of-variance and multiple regression/correlation approaches. New York: WH Freeman.

Kline, P. (1986). A handbook of test construction: Introduction to psychometric design. American Psychological Association. 750 First Street NE, Washington, DC 20002-4242, New York, NY, US: Methuen.

Koch, P., \& Hauknes, J. (2005). On innovation in the public sector - today and beyond. Publin Report No. D 20, 2(2nd ed.). NIFU STEP Studies in Innovation, Research and Education. Wergelandsveien 7, 0167 Oslo, Norway.

Kumari, G., \& Pandey, M. K. (2011). Job Satisfaction in Public Sector and Private Sector: A Comparison. International Journal of Innovation, Management and Technology, 2(3), 222-228.

Lala, L. P., Gheorghe, P., \& Monica, B. (2010). A theoretical approach of the concept of innovation. Managerial Challenges of the Contemporary Society; Conference Proceeding, 1, 151-156.

Lee, M. S., Hwang, T., \& Choi, D. (2012). Open Innovation in the Public Sector of Leading Countries. Management Decision, 147-162. https://doi.org/10.1108/00251741211194921

Leung, L. (2015). Validity, Reliability and generalisation in qualitative research. Journal of Family Medicine and Primary Care, 4(3), 324-327. https://doi.org/10.4103/2249-4863.161306

Lopez-Fernandez, O., \& Molina-Azorin, F. J. (2011). The use of mixed method research in the field of behavioural sciences.

Mafini, C. (2015). Predicting Organisational Performance through Innovation, Quality, and Inter-Organisational Systems: A Public Sector Perspective. The Journal of Applied Business Research, 31(3), 939-952. https://doi.org/10.19030/jabr.v31i3.9227

Maier, A., Brad, S., Nicoara, D., \& Maier, D. (2014). Innovation by developing human 
resource, ensuring the competiveness and success of the organisation. $2^{\text {nd }}$ World Conference on Business, Economics and Management. Procedia - Social and Behavioural Sciences, 109, 64-648. https://doi.org/10.1016/j.sbspro.2013.12.521

Manzini, T. S. (2014). Measurement of Innovation in South Africa: An analysis of survey metrics and recommendations. South African Journal of Science, 111(11/12), 1-8.

Marin-Garcia, A. J., Aznar-Mas, L., \& de Guevera, L. G. F. (2011). Innovation Types and Talent Management for Innovation. Working Papers on Operations Management, 2(2), 25-31. https://doi.org/10.4995/wpom.v2i2.926

Maydeu-Olivares, A., \& Lado, N. (2003). Market orientation and business economic performance: A mediated model. International Journal of Service Industry Management, 14(3), 284-309. https://doi.org/10.1108/09564230310478837

Meijer, S. S., Catacutan, D., Ajayi, C. O., Sileshi, W. G., \& Nieuwenhuis, M. (2014). The role of knowledge, attitudes and perceptions in the uptake of agricultural and agroforestry innovations among smallholder farmers in Sub-Saharan Africa. International Journal of Agricultural Sustainability, 13(1), 40-54. https://doi.org/10.1080/14735903.2014.912493

Meissner, D., \& Kotsemir. (2016). Conceptualising the innovation process towards the active innovation paradigm' - trends and outlook. Journal of Innovation and Entrepreneurship, 5(14), 1-18.

Messick, S. (1988). Validity. In R. L. Linn (Ed.), Educational Measurement (3rd Ed.). American Council on Education/Orix Press, New York, NY.

Ming-horng, W., Jih-Lian, H., Yi-Chou, W., \& Chung-Lin, T. (2012). A study of the relationship among service innovation, customer value and customer satisfaction: an empirical study of the hotel industry in Taiwan. The International Journal of Organisational Innovation, 4(3), 100-112.

Mongkol, K. (2011). The Critical Review of New Public Management Model and its Criticisms. Research Journal of Business Management, 5(1), 35-43. https://doi.org/10.3923/rjbm.2011.35.43

Morye, P. (2015). Definition, Meaning and Characteristic of Organisation.

Mulgan, G. (2014). Innovation in the Public Sector: How can public organisations better create, improve and adapt? Version 1, Nesta, London EC 4A 1DE.

Nagy, A. (2013). Approaching Service Innovation Patterns. European Journal of Interdisciplinary Studies, 5(1), 39.

Nanda, N., Kuruvilla, J. S., \& Murty, R. V. B. (2013). Role of Service Innovation in Customer Satisfaction and Customer Loyalty: A Study on Organised Retail in India. IJBIT, 6(2), 53-63.

Nkwe, N. (2012). E-Government: Challenges and Opportunities in Botswana. International Journal of Humanities and Social Science, 2(17), 39-48. 


\section{Mll Macrothink}

International Journal of Management Innovation Systems ISSN 1943-1384

Palinkas, L., Horwitz, M. S., Green, A. C., Wisdom, P. J., Duan, N., \& Hoagwood, K. (2016). Purposeful sampling for qualitative data collection and analysis in mixed method implementation research. Administration Policy Mental Health, 42(5), 533-544. https://doi.org/10.1007/s10488-013-0528-y

Petkovsek, V., \& Cankar, S. S. (2013). Public Sector Innovation in the European Union and Example of good Practice. Management, Knowledge and Learning, Croatia International Conference. CROATIA.

Pishgar, F., Dezhkam, S., Ghanbarpoor, F., Shabani, N., \& Ashoori, M. (2013). The impact of product innovation on Customer Satisfaction and Customer Loyalty. Arabian Journal of Business and Management Review, 2(7), 1-17. https://doi.org/10.12816/0002282

Popa, L. I., Preda, G., \& Boldea, M. (2010). A Theoretical Approach of the Concept of Innovation. Managerial challenges of the Contemporary Society, 1, 151-156.

Prifti, R., \& Alimehmeti, G. (2017). Market orientation, innovation, and organisation performance-An analysis of Albanian organisations. Journal of Innovation and Entrepreneurship, 6(8), 1-19.

Ramalingam, T., Karim, A. J., Piaralal, S., \& Singh, B. (2015). Creativity and Innovation (Organisational Factors) Influence on organisation's Performance: An Empirical Study on Malaysian Telecommunication Mobile Network Operators. American Journal of Economics, 5(2), 194-199.

Reguia, C. (2014). Product Innovation and the Competitive Advantage. European Scientific Journal, 1, 1-8.

Saari, M. L., \& Judge, A. T. (2004). Employee Attitudes and Job Satisfaction. Human Resource Management, 43(4), 395-407. https://doi.org/10.1002/hrm.20032

Sabir, M. H., \& Kalyar, N. M. (2013). Organisation's Innovativeness and Employee Job Satisfaction: The Role of Organisational Learning Culture. Interdisciplinary Journal of Contemporary Research in Science, 4(9).

Schutzenmeister, A., Jensen, U., \& Piepho, P. H. (2011). Checking Normality and Homoscedasticity in the General Linear Model Using Diagnostic Plots. Communication in Statistics - Simulation and Computation, 41(2), 141-154. https://doi.org/10.1080/03610918.2011.582560

Scotland, J. (2012). Exploring the Philosophical Underpinnings of Research: Relating Ontology and Epistemology to the Methodology and Methods of the Scientific. Interpretive and Critical Research Paradigms. English Language Teaching; Canadian Centre of Science and Education, 5(9), 9-16. https://doi.org/10.5539/elt.v5n9p9

Senguo, A. R., \& Kilango, C. N. (2015). Marketing Innovation Strategies for Improving Customer Satisfaction: Vodacom Tanzania. European Journal of Business and Management, $7(1), 127-132$. 
Shahzad, F., Luqman, A. R., Khan, R. A., \& Shabbir, L. (2012). Impact of Organisational Culture on Organisational Performance: An Overview. Interdisciplinary Journal of Contemporary Research in Business, 3(9), 975-985.

Silva, S. C. L., Kovaleski, L. J., Gaia, S., Garcia, M., \& de Andrade Junior, P. P. (2012). Cost Deployment Tool for Technological Innovation of World Class Manufacturing. Journal of Transportation Technologies, 3, 17-23. https://doi.org/10.4236/jtts.2013.31002

Stanton, M. J. (2001). Galton, Pearson and the Peas: A Brief History of Linear Regression for Statistics Instructors. Journal of Statistics Education, 9(3), 1-11. https://doi.org/10.1080/10691898.2001.11910537

Statistics Botswana. (2016). Agricultural Censors Stats Brief 2015. Government of Botswana.

Tabachnick, G. B., \& Fidell, S. L. (2001). Using Multivariate Statistics (4th ed.). Needham heights, MA: Allyn and Bacon.

Tajuddin, M. Z., Iberahim, M. H., \& Ismail, N. (2015). Relationship between Innovation and Organisational Performance in Construction Industry in Malaysia. Universal Journal of $\begin{array}{llll}\text { Industrial and Business } & \text { 87-99. }\end{array}$ https://doi.org/10.13189/ujibm.2015.030402

Tan, C. L., \& Narsudin, A. M. (2011). Human Resource Management Practices and Organisational Innovation: Assessing the Mediating Role of Knowledge Management Effectiveness. The Electronic Journal of Knowledge Management, 9(2), 155-167.

Taylor, R. (1990). Interpretation of the Correlation Coefficient: A basic Review. Journal of Diagnostic Medical Sonography, 6(1), 35-39. https://doi.org/10.1177/875647939000600106

Tshukudu, T. T. (2014). Decentralisation as a strategy for improving service delivery in the Botswana public service sector. Journal of Public Administration and Governance, 4(2), 40-48. https://doi.org/10.5296/jpag.v4i2.5719

Udegbe, M. I., \& Udegbe, S. E. (2013). Impact of Product Development and Innovation on Organisational Performance. International Journal of Management and Sustainability, 2(12), 220-230.

Vogoda-Gadot, E., Shoham, A., Schwabsky, N., \& Ruvio, A. (2005). Public Sector Innovation for the Managerial and the Post-Managerial Era: Promises and Realities in Globalising Public Administration. International Public Management Journal, 8(1), 58-81.

Waiganjo, W. E., Mukulu, E., \& Kahiri, J. (2012). Relationship between Strategic Human Resource Management and Organisation Performance of Kenya's Corporate Organisations. International Journal of Humanities and Social Science, 2(10), 62-70.

Wainaina, G. N., \& Oloko, M. (2012). Market Penetration Strategies and Organisational Growth: A Case of Soft Drink Sector in Kenya. International Journal of Management and Commerce Innovations, 3(2), 219-227. 


\section{Macrothink}

International Journal of Management Innovation Systems

ISSN 1943-1384 2018, Vol. 3, No. 1

Wegrich, K. (2017). Public Sector: Economics. Public Sector Economics Journal, 41(2), 137-293.

Wright, E. R., Palmer, C. J., \& Perkins, D. (2004). Types of Product Innovations and Small Business Performance in Hostile and Benign Environments. Journal of Small Business Strategy, 15(2), 33-44.

Yeh-Yun, L. C., \& Yi-Ching, C. M. (2007). Does innovation lead to performance? An empirical study of SMEs in Taiwan. Management Research News, 30(2), 115-132. https://doi.org/10.1108/01409170710722955

Yi, Y., \& Gong, T. (2009). An integrated model of customer social exchange relationship: The moderating role of customer experience. The Service Industries Journal, 29(11), 1513-1528. https://doi.org/10.1080/02642060902793474

Yoo, W., Mayberry, R., Bae, S., Singh, K., He, P. Q., \& Lillard, W. J. (2014). A Study of effects of multi-collinearity in the multivariable analysis. International Journal Applied Science Technology, 4(5), 9-19.

\section{Copyright Disclaimer}

Copyright for this article is retained by the author(s), with first publication rights granted to the journal.

This is an open-access article distributed under the terms and conditions of the Creative Commons Attribution license (http://creativecommons.org/licenses/by/3.0/). 